\title{
Cultures of the Body, Medical Regimen, and Physic, at the Tudor Court
}

In the summer of 1516, Leonardo da Vinci moved permanently to France. King Francis I invited the famous artist to become his 'Paintere $d u$ Roy'. ${ }^{1}$ It was a lucrative and prestigious appointment. The position of Court Painter paid a generous pension of ' 1000 scudi per annum'. For health reasons, Leonardo needed better patronage. Entries in his private notebooks reveal that the famous artist had been ill with mild paralysis on the right side of his body. In France he was seeking better climes, financial security, and improved medical care. On arrival Leonardo adopted a new medical regimen to aid his recuperation. He copied down 'a recipe for better physic' that was in circulation at the fashionable centres of European medical education at Bologna, Padua, and Paris. Before long the regimen had crossed the English Channel and was being promoted by the medical fraternity of Tudor London too. Its translation advised courtiers:

If you want to be healthy observe this regime.

Do not eat when you have no appetite, and dine lightly.

Chew well, and whatever you take into you

Should be well cooked and of simple ingredients.

He who takes medicine [self-doses] is ill advised.

Beware anger and avoid stuffy air.

Stay standing a while when you get up from a meal.

Make sure you do not sleep at midday.

Let your wine be tempered [mixed with water], taken a little and often,

Not between meals, nor on an empty stomach.

Neither delay, nor prolong your visits to the privy.

If you take exercise, let it not be too strenuous

Do not lie with your belly upward and your head

Downward. Be well covered at night,

And rest your head and keep your mind cheerful.

Avoid wantonness and keep to this diet. ${ }^{2}$

This type of dietary advice was well-known during the reign of King Henry VIII (1509-47). Contemporary accounts confirm that the monarch was fascinated by humanist learning and the latest early modern physic. ${ }^{3}$ But Leonardo's cautious regimen was not for Henry. The English monarch loved all of the physical pleasures that the doggerel sonnet 
recommended a European courtier should avoid. The Venetian ambassador wrote in 1531 that the king:

is accomplished in every manly exercise, sits his horse well, tilts with the lance, throws the quoit, shoots with the bow excellently well, is a fine tennis player, and practices all these gift with the greatest industry ... He is kind and affable, full of graciousness and courtesy, and is liberal, particularly to the men of science, who is never weary of obliging. ${ }^{4}$

Henry was, according to these diplomatic reports, renowned for his romantic nature and a 'superabundance of nervous energy'. The Milanese ambassador, Paolo da Lodi, likewise reported of the young king that: 'He is never still or quiet ... He does wonders and leaps like a stag' at dancing. ${ }^{6}$ He adored the 'wantonness' of sex, ardently lovemaking his mistresses and wives in the royal bedchamber (though no evidence survives that he did so at the same time!) Henry believed in vigorous exercise on the hunting field; he often jousted dangerously risking grave personal injury; and hawked despite his failing eyesight into old age. ${ }^{7}$ His appetite like that of most noble families who celebrated being fatter as a sign of wealth was nonetheless notable. Henry snacked between meals, ate huge portions and consumed rich ingredients. Accounts from the kitchens of the royal palaces show that Henry relished red meat. He could not have known the modern science of nutrition but he did physically experience how difficult a high-protein diet is to digest and hard for his blocked bowels to expel (unlike Leonardo, a famous vegetarian). In the Calendar of State Papers detailed records survive of the food served to those that ate in the Privy Chamber. An entry in 1526 for example attests that Henry personally ordered a 'flesh day' each week 'frome Estir [Easter] untyll Mychellmes [Michalemas]', and that when he brought his illegitimate son, Henry Fitzroy, duke of Richmond and Somerset, to court (around June 1525) he decreed his diet to be:

An ordinary diet by estimation for my Lord's persone, his bords ende, and for his chambre and household ... 
First course:-Pottage; boiled meat, 12d.; beef and mutton 8d.; 4 green geese, 20d.; 3 roast capons, $3 s$.; 1 q. of roast veal, $9 d$.; fryaunce or custard, $16 d$. Second course:-Half a lamb or kid, 12d.; 6 rabbits, 10d.; 14 pigeons, $6 d$; a wildfowl, $2 s . ;$ "tairt or bakenmete," $16 d$; fructor, $2 d$.; ... trenchers, for his dener with wayters, $8 d . ; 4$ gal. ale, $4 d$; 2 pitchers of wine, $16 d$.; fruits, $6 d .=17 s .1 d^{8}$

Ten portions of meat in two courses took their toll on the royal digestive system (despite the pudding fruit). Small wonder perhaps that Henry VIII's suits of armour kept expanding in size. Those on display at the Tower of London today reveal his torso measurements:

1514

Age

Height

Chest circumference

Waist circumference
23

6 feet 2 inches

42 inches

35 inches
1536

45

ditto

45 inches

37 inches
1541

50

ditto

57 inches

54 inches $^{9}$

In middle age the royal apothecaries were often summoned to cure the king's painful constipation. Being overweight necessitated prolonged visits to the privy. ${ }^{10}$ Henry’s thirst was said to be 'unquenchable'. Naturally he drank lots of red wine, since local water supplies were considered a health hazard, but then he needed to urinate frequently. At night he suffered restless sleeping patterns, cat-napping in the day to try to cure his insomnia. Taken together, contemporary evidence strongly suggests that Henry was neither a perfectly balanced man, nor someone who followed strict medical advice. The handsome prince needed to adopt a healthier lifestyle before middle age slowed his metabolism. Instead Henry's medical regimen was an idiosyncratic reflection of his changeable personality. ${ }^{11}$

Henry nonetheless took a prestigious interest in the reconstitution of the Tudor medical world for two reasons. Disease was very common and people expected to be sick more often. He also had important intellectual and political motivations for paying attention 
to the latest cures. The king was a keen scholar and studied famous humanist texts on the body as an expression of his authority. Henry likewise recognised that the dissolution of the monasteries destroyed not only the religious power of the Catholic church, but a pivotal system of community healthcare too. ${ }^{12}$ In times of necessity and social upheaval this had to be replaced with alternative lay medical services. That process entailed a fundamental reorganisation of the traditional medical fraternity (physicians, barber-surgeons and apothecaries) that served the court, metropolis and provincial English towns. How this transition in expertise was managed in the light of Henry's personal medical preferences has occupied historians of medicine. ${ }^{13}$ They have been keen to unravel to what extent the monarch's medical mentality extended, or limited, his royal influence during a crucial phase of the early Reformation process. Key questions remain unanswered about the ways in which Henry directly, and indirectly, influenced the medical regimen of daily life in Tudor England. More archive work is needed to establish how popular his official reach was when it came to managing illness, reforming doctoring standards, and what part those new lay services (regular and irregular) played in maintaining his royal authority. This chapter thus explores three medical perspectives of Henry's kinship.

It begins by briefly setting Henry's medical mentality in its historical context. Section one explores common Tudor beliefs about better physic. Section two engages with some of the support staff connected to the daily life of the court. We are introduced to the extended retinue of staff in the pay of a minor noble landed family, the Cholmleys of Yorkshire who lived both at court and in the North of England: an area often neglected in the social history of medicine. Using contemporary household accounts overlooked in local archives can help us start to illuminate the shadowy social spaces of royal palaces like Hampton Court. Those servants played vital medical roles in the birthing rooms, kitchens, stillrooms, and herb gardens of court life. In the third section the influence of elite women and their practical 
medical care is re-examined. It will be shown that female kinship helped to maintain basic doctoring and nursing standards at court too. Often regimen was passed amongst educated females that connected together larger noble households. Those links were maintained and managed through regular conversations between contemporaries, a method of sharing knowledge about better physic termed talking 'chest-to-chest' in Tudor times. ${ }^{14}$ It often happened inside birthing suites where close relations and wider kinship ties congregated in a private female medical space. This family physic had a privileged medical discourse. It spoke of the need for the strong physical presence of certain bloodlines at court. It was those birthright claims that came to symbolise the resilience of the body politic of the Tudor court and, by association, King Henry VIII's physical power and medical well-being on the English throne.

\section{I.}

Antiquarianism was a fashionable pursuit at the Tudor court for dynastic and medical reasons. ${ }^{15}$ Establishing a family's bloodline was imperative for all noble families. ${ }^{16}$ Precedence dictated access to the physical body of the monarch at court. The dukes of Norfolk were for instance renowned for their proud bearing. ${ }^{17}$ They occupied lavish suites of rooms in the royal palaces by virtue of their birthright claims and vast wealth. The head of the Fitzalan-Howard family (cousins of the Boleyns) was one of the richest men in Europe. In battle he had also earned his position as hereditary Earl Marshal of England, responsible for calling men of noble birth to arms in time of war. This gave the family unique access to patronage and the centre of power. The duke of Norfolk thus played a prominent heraldry role in courtly life. He managed the Royal Court of Chivalry with the Garter King of Arms and Lord High Constable of England. This remains even today one of the oldest civil courts, governed by heraldry statutes dating from 1066. It has the legal responsibility for monitoring the legitimacy of noble birthright. ${ }^{18}$ In the collection of the Royal College of Arms many 
disputed bloodline claims survive in the antiquary books of heralds. Most are filled with family trees. They also contain important, little appreciated, medical and religious doggerel. It is common to find medical recipes amongst the folios because better physic was essential if a family's bloodline was to survive into adulthood. Regeneration depended on good regimen advice. It often had a strong religious element too. A typical entry for the heraldry book of Lord Mountjoy, leading member of the Privy Chamber and Henry VIII's 'socius studiorum' (companion in studies), has survived in the Vincent Collection. ${ }^{19}$ It reads:

I am confessest I trust the Priest I beat my Backe and Brest my Fyst With Holy Water to be Present And with contrition I all recant I pray to God and Heavenlie Host I crosse myself at every Post I eate my Maker in the Breade I deale my Dole when I am Deade And thus I think that well I may My very all Sinnes soon put away. ${ }^{20}$

In many respects, Mountjoy’s doggerel summarised Henry's basic medical and spiritual beliefs. During the early part of his reign, the Catholic church was the mainstay of his religious outlook, with its creed of transubstantiation, charity to the poor, confession to a priest, followed by penance and absolution. ${ }^{21}$ Canon law also decreed that it was sometimes necessary to bear physical pain as a punishment for mortal sins like fornication. If good health was God-given, then devilish behaviour could bring about life-threatening illness. The Tudors believed that divine judgement should ideally be borne with stoicism. ${ }^{22}$ Nonetheless during sickness a family priest was called to provide daily solace in the form of regular prayers for the penitent sinner. A trusted family apothecary co-ordinated pain management since the fate of the patient was believed to be finely balanced in the heart. The sincere repentant who had access to medical skills could survive the deathbed scene, but many believed that self-dosing remedies were never effective without the power of contrite prayers. 
For Henry VIII religious ritual and better physic were always intimately connected to the actual bodily function of court life.

Henry had been brought up to believe in the power of divine intervention and that a monarch was closer to God than his subjects: a theme reiterated in several chapters of this book. From a medical standpoint, this also placed him in a unique position at the head of the body of the court. In his Latin studies he read in First Corinthians Chapter 12 that the scripture reaffirmed this social order with physical metaphors. Verse 14 advised that the 'body is not one member, but many'. ${ }^{23}$ The foot it stated needs the hand, just as the ear needs the eye (verses 15-16). Likewise all five senses were essential for the whole body of mankind to function healthily (verses 18-19). In the body of the Tudor court there were the Bible said multiple talents. Verse 28 reminded each subject that "God hath set some in the church, first apostles, secondarily prophets, thirdly teachers, after that, miracles, then gifts of healings, helps, governments, diversities of tongues". The king commanded them all, but he also had a duty to 'care for the sick, and the comely', like natural fools (verse 23 ) ${ }^{24}$ Henry knew that 'God hath tempered the body together, having given more abundant honour to that part which lacked'. He could not therefore in good conscience be a tyrant and destroy at will because in so doing, he would hurt his physical command of the whole body of the kingdom. In the Tudor imagination, a balanced nation depended on a level-headed king who ruled with good heart.

In his personal habits, Henry, like his Tudor subjects, followed a standard Galen regimen, espousing the balance of the four bodily humours. ${ }^{25} \mathrm{He}$ did so for medical and political reasons. A people must look to their king, but a monarch must also mirror his subjects. A Christian sovereign was duty bound to take the moral and physical lead by being of a balanced body and sound mind. If he did otherwise his royal tree might not endure the ravages of two dread words, disease and death. Noble families often echoed this medical 
mentality in their family shields. One such for the Cholmondley family of Cheshire prayed: “Our Handy work, like to Ye fruitful Tree, Blesse Thou, O Lord; Let it not Blasted be'. ${ }^{26}$ Those sentiments expressed the fact that the fates could be cruel, medical misfortune destroying a family line in one generation. It was for this key reason that from birth the court soothsayers eagerly studied Henry's birth chart. At the time, Henry was the second son and not due to inherit, but life was unpredictable for everyone especially royal children. The heir and spare, Prince Arthur and Henry, were crucial for the line of succession. What the soothsayers cast in Henry's case was a complicated medical future.

A child such as Henry born under the astrological sign of cancer, on the 28 June 1491, was said to be governed by the watery and maternal cycles of the moon. ${ }^{27}$ The court soothsayers predicted that the baby prince would suffer from common diseases normal for his birth sign. These included agues, coughs, chlorosis, general fevers, green sickness, quinsy, rheumatism, smallpox and gallstones. The heavenly planets on the day of his birth were then plotted in two ways. ${ }^{28}$ On the sinister side of his mother's heraldry and bloodline there were said to be favourable family attributes. Henry would inherit a cheerful, frivolous and flirty disposition, growing into a man of action. On his father's dexter side however the soothsayers forewarned of excessive personality traits. They saw a short-temper, someone over-sensitive to personal criticism, a person inclined to over eat and drink too much alcohol. The prince would be troubled in adulthood by restless sleeping patterns, excessive wet dreams, inclined to blinding headaches, painful constipation, and a tendency to worry from his paternal line. These predictions proved to be remarkably prescient. Henry's 'maladies of the mind', described by the soothsayer, were above all to trouble his romantic history. ${ }^{29}$ It was for this reason that music would be his chief medicine, a traditional cure for love sickness and melancholy. ${ }^{30}$ 
The royal soothsayers saw that the key to Henry's medical future lay in his heart. ${ }^{31}$ This delicate instrument they forewarned would need to be tempered otherwise he could pay excessive attention to lovemaking and courtly romance. ${ }^{32}$ To appreciate fully why Henry proved to be such a predictable romantic character, it is important to delve deeper into his family psyche. Margaret Beaufort, Henry's grandmother, bequeathed a terrible medical standard to her grandson. ${ }^{33}$ At just thirteen years old she gave birth to King Henry VII (Henry's father). The birth was painful and prolonged. The court records suggest that her womb prolapsed, but she had done her duty and fulfilled her destiny. ${ }^{34}$ In the childbirth room her only male heir secured the Tudor line of succession. Margaret Beaufort forfeited her future fertility for dynastic ends. Henry VIII could not fail where his grandmother had sacrificed her womb to succeed. This meant that with age Henry became an obsessive husband. Diplomatic reports from court all agreed that the king was believed to be an affectionate and skilful lover, but few also failed to notice that Henry harassed his wives for a male heir in the bedchamber. ${ }^{35}$ Frequent miscarriages and stillbirths beleaguered his six marriages. In this he may have been no different from the noble families and subjects that staffed the court, but his medical failures seemed to symbolise a deeper malaise in his dexter (paternal) bloodline. Henry's physic threatened to be unbalanced by the carnal desires of the flesh versus a ruthless sexual drive for dynastic ends. At court the midwives connected to the birthing chambers watched and waited to see what destiny had in store for Henry Tudor. ${ }^{36}$ And they were not alone, for the court was a crowded medical space. It was peopled by a complex array of support staff that cared for the well-being of the body politic. Recent research on the medical archives of noble families will be used in the next section as an historical prism to illuminate this shadow world in which copious historical actors played their parts in the everyday physic of Tudor life. 
In the fifth year of King Henry VIII's reign, Sir Roger Cholmley, a native of Cheshire, rode on a fast horse to court to be knighted. On arrival, he was described by one chronicler as a 'black, proper, and stout man'. ${ }^{37}$ Through a judicious marriage he had been enriched by landed estates in Yorkshire. He had also earned a fearsome reputation for brutality and military prowess in the Northern Lands. This though was tempered by loyalty to his large retinue who lived in 'great port' at Roxby near Pickering close to Scarborough. Like many ambitious landed magnates, Sir Roger Cholmley understood the importance of making an impressive entrance at court. He always travelled with a large extended household 'comprising at least fifty or sixty men-servants'. ${ }^{38}$ They were employed to feed, protect, and boast of his noble standing. In this he copied the modus operandi of his noble patron, the Percys of Alnwick Castle in Northumberland. The family later became closely tied to the Howards of Henderskelfe, known today as Castle Howard, near Malton in Yorkshire. ${ }^{39}$ Misfortune meanwhile struck Sir Roger on the $28^{\text {th }}$ April 1538. He died at court from a summer fever, a condition greatly feared by King Henry VIII. The court was such a crowded and contagious medical space that few could escape the ravages of disease in noxious years when the weather was stagnant and the river water flowed with effluent. Sir Roger Cholmley was succeeded by his eldest and only legitimate son, Sir Richard Cholmley. ${ }^{40}$ The heir was said to be 'tall of stature and withal big and strongly made, having had in youth a very ably body'. When Sir Richard arrived at court in some style in 1539 the family chronicler noted that 'his hair was black, his eyes the same hue, and his complexion a clear brown'. He was soon known by his fellow courtiers as 'the Black Knight of the North', a tribute to his physically imposing appearance and robust ancestry. There were though other important reasons for his notoriety at court, and these illuminate the pivotal role that family physic played in courtly life. 
Sir Richard Cholmley was said to be 'extraordinarily given to the love of women'. ${ }^{41}$ He married 'when young Margaret, the daughter of Lord Conyers' from Norton Conyers near Ripon in North Yorkshire. Like many females she died in childbirth and before long Sir Richard had courted and won the hand of a noted beauty, Lady Catherine Clifford in 1533. Catherine was the 'beautiful widow of Lord Scrope of Bolton Castle' and her mother was Lady Margaret Percy, Countess of Northumberland. It was an ambitious and important blood alliance for the Cholmleys. This however was when the family troubles began and what brought their kinship ties to the personal attention of the Privy Chamber and King Henry VIII. Sir Richard's new wife, Lady Catherine, held strong opinions. It was said by the Cholmley family recorder that she was 'not a woman to be gainsaid in love'. ${ }^{42}$ After the birth of their first child, she found out that Sir Richard had strayed during her long confinement in the birthing rooms at court. The same family history records that a long and bitter dispute arose about the sexual conduct of Sir Richard. Husband and wife became a warring faction. As a beautiful woman Catherine expected, if not total fidelity, at least discretion and loyalty in public. Sir Richard however did not see why he should limit his affections or wandering eye to one woman. At court, the Cholmley marital dispute was attention-seeking. Sir Richard paraded his affronted manhood rebuffed by Lady Catherine's chiding; she cleverly was said to have withdrawn conjugal rights in the bed chamber until his sexual conduct mended. When affronted, she flirted and flouted her renowned beauty inflaming his desire. Eventually, they reconciled for reasons of birthright. Their first child was a girl and Sir Richard was desperate for a male heir to secure the noble standing of his bloodline. ${ }^{43}$ To do otherwise would make a mockery of his dynastic marriage to Catherine. Birthright was pointless without the correct birthing, and for this reason Sir Richard maintained a large medical retinue at court.

Sir Richard Cholmley, like his father, was said by his family chronicler to 'always like to have a great train of menials about his person'. ${ }^{44}$ This suited his generous, gregarious 
and genial personality. There were cooks to prepare his meals and apothecaries to watch his diet. Herbalists prepared medicinal remedies and barber surgeons bled the extended family retinue in the spring (pregnant women and young children were excluded on health grounds). So many people surrounded Sir Richard that the household accounts show that 'there used to be as often as many as twenty four pieces of beef put in the morning in the pot, yet sometimes it so happened that but one would be left for Sir Richard's own dinner'. ${ }^{45}$ It was a family custom, maintained at court, to provide physic and good food to family servants as part of their daily medical regimen. A chronicler described how 'the idle serving men, it appears, were accustomed to having their breakfast... and going into the kitchen would use their liberty to stick their daggers into the pot and take out the beef without the leave or privacy of the cook'. Sir Richard remained, by all accounts, good humoured when served small portions at mealtimes. It was said that he 'would merely laugh and cry out, What! Would not the knaves leave me one piece for my own dinner'. Evidence like this alerts historians of medicine to the complexities of household regime and the number of historical actors that were in both temporary and permanent residence at Court by the 1530s. Looking closer at the medical records and reading material of the Chomley retinue is instructive.

Commonplace and conduct books in the sixteenth century were popular amongst those that managed households connected to noble families. ${ }^{46}$ This was especially true of ambitious magnates like the Cholmleys. Many hoped to raise the social standing of their bloodlines to the first ranks of the peerage. It was necessary however to first study in detail what some early modern historians have called a 'silent language' of nobility. ${ }^{47}$ Richard Verstegan looked back at this private discourse and the close knit circle of people that physically surrounded the Tudor monarchs in his treaty A Restitution of Decayed Intelligence published in Antwerp in 1605. He elaborated what contemporaries called the 'etymology of 
social degrees'. There was a subtext of medical meaning behind the tacit language of each noble family's bearing in the Tudor world. Verstegan explained:

Now was it usual in long foregoing ages, that such as were endued with great wealth and means above others, were chiefly renowned ... for their housekeeping and good hospitality, that is for being able and using to feed and sustain many men, and therefore were particularly honoured with the name and title of HLAFORD, which is as inasmuch to say, An afforder of laf, that is a bread-giver..

And if we duly observe it, we shall find that our nobility of England, which generally do bear the name of Lord, have always, and as it were of successive custom (rightly according to that honourable name) maintained and fed more people to wit, of their servants, retainers, dependants, tenants, as also the poor, than the nobility of any country in the continent, which surely is a thing very honourable and laudable, and most well befitting noblemen, and right noble minds... ${ }^{48}$

Verstegan then revealed that the title of 'Lady' was derived from LEAFDIAN, that is breadserver:

Whereby it appeareth that as the LAFORD [Lord] did allow food and sustenance, so the LEAFDIAN [Lady] did see it served and disposed to the guests, which custom of ladies carving and serving continue to the present. ${ }^{49}$

He elaborated that the food of the stomach, the mind, and the womb were all intrinsic aspects of the etymology of noble titles, 'Lord' and 'Lady'. This was the spirit, as well as the letter, of the law of nobility. It was derived from the Royal Court of Chivalry overseen by the College of Arms. Importantly if birthright was its basis, then birthing created a strong sense of connected communities, what Noble contemporaries often called 'our college'. Bloodlines were nourished in the womb by spiritual sustenance and the physic of ages past, just as the breaking of the bread was central to religious ritual and at physical mealtimes was medicine for the corporeal body. ${ }^{50}$ This type of commentary suggests that although patriarchy and primogeniture inheritance structured the Tudor nobility, medical regimen broadly defined was pivotal too. Returning to the Cholmley retinue, the females connected to the extended household played crucial roles in this private world of medical meaning. 
Sir Richard's mother, the former Lady Katherine Constable of Flamborough Castle, had a remarkable medical history in an era of death, dearth, and disease. ${ }^{51}$ She bore successfully eight children who all survived to adulthood and made successful marriages to the Cliffords (Bolton Castle), Percys (Alnwick Castle), Gascoignes (Ravensworth Castle), Conyers (Conyers Norton) and the junior branch of the Cholmleys (Whitby Abbey). These family ties reiterate that the dichotomy of court life - centre and periphery - is too simplistic. ${ }^{52}$ There were a northern circuit of families that connected to the main southern court, and these intersected both in the capital and during the monarch's summer visitations to the provinces. What this meant was that from a medical standpoint, there was a complex household geography in operation. Large circles of kinship enabled females to converse and pass on their medical expertise 'chest-to-chest' at home; amongst their neighbours when sharing herbal cures; and on arrival at court. These observations accord with Barbara Harris's recent work on the human abilities and fascinating hidden lives of English aristocratic woman in early Tudor times. ${ }^{53}$ They had to navigate complex legal standards when it came to retaining property rights for their progeny, yet, proved to be more than capable of efficient household management. Most females developed good communication skills with each other, especially during risky childbirth, even if they remained competitive in the marriage game. ${ }^{54}$ This meant that the Cholmley women that reproduced successfully, surviving childbirth on a regular basis, were known by repute, and this makes their physic an important historical prism for historians of medicine. In this article the life of one elite member of the family, Lady Margaret Cholmley, sets in context the role that many women played in the medical sphere of the court, and elsewhere.

III. 
Raby Castle near Staindrop in the Palatine of Durham was the powerhouse of the Neville family in the North of England. ${ }^{55}$ It was a fortress that protected their kin and household from the ravages of warfare in the 'diabolical lands' bordering Scotland. The landscape had a rugged beauty, reflected in the grey-coloured worsted-wool clothing of the local populace. Lord Henry, fifth earl of Westmorland lived at Raby and commanded loyalty from the minor landed gentry stretching as far down as Middleham in mid-Yorkshire across to Scarborough on the Lincolnshire Wash. It was a sizeable inheritance. ${ }^{56}$ On 3 July 1536 , aged eleven, Lord Henry Neville was bequeathed in marriage to Lady Anne Manners at court. She was the daughter of the earl of Rutland who resided at Haddon Hall in Derbyshire and Belvoir Castle near Grantham in Lincolnshire. Like many Tudor courtiers they were contracted in marriage early but their physical union was not consummated until puberty. ${ }^{57}$ They then had in quick succession three girls and so there was a lot of anxiety about securing the Neville bloodline with a male heir. Anne became pregnant for a fourth time at the end of Henry VIII's reign and gave birth to a longed for boy, christened Charles in 1547-8. Unfortunately like many early modern women, Anne died soon after giving birth from a 'discharge of her womb' (the same fatal condition as Jane Seymour, Henry VIII's third wife). The most likely cause was sepsis, or its common name, childbed fever. Henry Neville was a delighted and downcast man. He had a precious male heir, but had lost a wife. Like many noble families with just one male child it was a priority for him to marry to secure an heir and spare. Meantime Sir Richard Cholmley, through his marriage to Lady Catherine Clifford, had raised his family's standing at court. This placed him in the social ambit of those nobles of the first rank close to the dying king. Through those intimate bloodline connections he proposed a dowry for his eldest sister, Jane, to marry into the Neville family. Jane was delighted to be bequeathed to one of the premier earldoms but her pre-marital joy proved to be short-lived. 
Family histories recount that Jane Cholmley was a loving stepmother to the four Neville children, but Henry, their father, was a boisterous man. ${ }^{58}$ Many at court blamed him for the death of his first wife - though she died in childbirth - others said that she was worn out with his philandering ways. Henry Neville was certainly wild in his youth. He loved the intrigue and high spirits of court life, by birth being intimately connected to the inner circle of the Privy Chamber. Like Henry Norris, he ran with the king's crowd. He was a fortunate young man in a privileged position. Importantly, he never lost favour with Henry VIII because for a key family reason he was protected from the worst ravages of court politics. Following the Pilgrimage of Grace, successive Tudor monarchs needed a strong presence in the Northern lands. ${ }^{59}$ The failure of the rough wooing by King Henry VIII of Mary (later Queen of Scots), proposed for a short time as a future wife of Prince Edward, meant that the Neville estates were in a convenient location to protect the monarch's territorial interests bordering Scotland. If Henry Neville misbehaved, it was judged prudent to tolerate his noble foibles. His second marriage to Jane meanwhile was fraught with medical difficulties because she could not conceive. This made her a bad marriage bargain in the eyes of the court. Jane turned to the comfort of her mother, the former Lady Katherine Constable who had been remarkably successful in childbirth. She also consulted her younger sister, Margaret, who was said within the family 'to have a gift of healing'. ${ }^{60}$ The circumstances of Margaret's life and her skills in physic came to light at several church court hearings because of her respected medical knowledge. In so doing, her life represents a new trend in the history of medicine.

The recent research project of Peregrine Horden on the household medicine of the Cecil family has reconstructed the functional roles that many elite women played in Tudor physic. ${ }^{61}$ It has established that the Cecil women were learned in Greek and Arab medical books, and that they were more hands-on than had previously been documented. ${ }^{62}$ The meticulous records kept at Hatfield House and several Oxford colleges have revealed a 
fascinating private world of physic. Lady Mildred Cecil (nee Cooke), Sir William Cecil's second wife, for instance, was connected to a network of educated females who shared their expertise in physic, as well as material goods. These connections tended to be with the head of a noble family that also held a powerful political position at court. There was also usually a neighbourly connection in terms of nearby country estates. ${ }^{63}$ A lot of noble women returned from court via landholdings in Northamptonshire for example because of its central location in the Midlands on the Great North Road. This made it an ideal stopping off point between the court and elsewhere. Throughout Tudor times the county was filled with gentry holding high-office. Major new houses would be built by ambitious courtiers like Sir Christopher Hatton at Holdenby or refurbished by the Mildmays who acquired Apethorpe Hall. As Linda Pollock has documented in some detail, the Elizabethan females of the Mildmay family were known for their medicinal skill. ${ }^{64}$ This was the social ambit of Lady Margaret too, since she was skilled at childbirth.

The consistory court records suggest that Lady Margaret may have inherited basic birthing skills from her mother, Lady Katherine Constable. ${ }^{65}$ This meant that with her small, narrow hand she could feel inside the womb in the last stages of labour if the newborn got stuck in the birth canal. The court testimony indicates that the hand was a very important medical instrument for women who experienced painful births; the most likely explanation being that they had a narrow pelvis or they did not dilate fully in labour. Lady Margaret was not labelled a midwife, because that would have been socially unacceptable, but she did act as a birthing partner, the early modern equivalent of a doula. The court evidence and a family portrait that survives in Whitby museum also indicate that Lady Margaret carried a small birthing book which hung from a chain around her waist. The suggestion is that it looked like a traditional girdle book that Lauren Kassell has described in regular use by the seventeenth century. ${ }^{66}$ Contemporary accounts indicate that it contained words and pictures to show 
women frightened by birthing what sort of practical help Lady Margaret could provide in an emergency. ${ }^{67}$ Herbs for example for pain relief, like mandrake, were described. Anatomical images showed the physical stages of childbirth in a rudimentary manner presumably to calm a worried female frightened by the experience of painful labour. A Sarum court record towards the end of her life thus described Lady Margaret as 'a pious woman but in the habit of pitying others and doing God's work amongst them to rescue their souls' ${ }^{68}$ She was 'modestly and Godly attired and disposed respectably to all in her neighbourhood'. This phraseology needs to be carefully set in its historical context. There was self-evidently an intimate connection between her nobility (as Bread-Server, the Leafdian household role, referred to above) and Lady Margaret's charitable duties expected of her sex and social class. She also had a strong religious belief, and this she practiced in the care of the sick, especially as an elite woman who attended birthing chambers. Often a midwife registered with a Bishop would have to quickly christen a newborn whose life was in danger, or send for a priest to give the last rites to a dying mother. ${ }^{69}$ Lady Margaret would have been on hand to assist. There was though a dangerous side to this work too. To appreciate the difficult position that Lady Margaret found herself in, it is necessary to return to the sad circumstances of her sister Jane's barren marriage.

In 1558, Jane Neville, countess of Westmorland, was found dead in bed. Death was not an uncommon experience for elite women since everyone had a lower life expectancy, but there was a medical mystery surrounding her fatal symptoms. After all, it was wellknown that Jane could not conceive so she did not die in the birthing room. Nor were there any local reports that she suffered from a contagious disease or accidental injury. Instead the gossips said that Henry had poisoned his barren wife to free himself from the bonds of an infertile marriage. These accusations came to light because Henry quickly proposed to Lady 
Margaret. Church doctrine however forbid close blood ties in marriage, and so there was a scandal about the 'sororate marriage' in the Neville clan, as described below:

A sororate marriage is a preferential marriage, the union of a widower with a sister of his deceased wife; the custom by which a man may marry one or more of sisters-inlaw, especially when his first wife has died, or has proven to be barren. A widower who marries his sister-in-law can be said to enter into sororate marriage, only if that kind of marriage already exists as a preferential or institutionalized norm in society. The sororate marriage existed in Biblical times, but was outlawed by the Christians, so most of the examples we encounter in European history should be classed as incest. Henry Neville (1524-1563), 5th Earl of Westmorland, married Jane Cholmeley and Jane's sister, Margaret Cholmeley, and this rare example of sororate marriage provoked an investigation of His Lordship's sexual life. ${ }^{70}$

The question being asked was did Lady Margaret use her healing skills to practice the 'darker arts of physic'. Did she collude to poison her sister? Maybe she tempted Henry Neville with a love potion? Perhaps it was Henry that administered the fatal physic? Many courtiers thought that the Earl's sex life should be investigated more closely. John Hales, the radical pamphlet writer from Kent, claimed that there were dangerous secrets lurking in Henry Neville's sexual past. He alleged these stretched back to his wild youth. It is worth recalling that Henry Neville was born in 1525 and first got married in 1536 just several months after Henry VIII had ordered the beheading of Anne Boleyn. He was closely associated with the youthful excesses of the Privy Chamber. It was a time of head strung romantic storms, with their serious political fallout, that seemed to beleaguer the Tudor Nobility surrounding the king. By the time Henry Neville's second wife Jane died from poison, he had grown into a thirty-three year old widower who still seemed to symbolise debauchery. Lady Margaret meanwhile was just twenty-five and soon the subject of suspicion. John Hales thought there was no smoke without fire. He circulated a forty-one page tract written in Latin, later published in 1562 - John Hales's 'Comes Westmerlandiae ducit in uxorem sororem uxoris demortuae, Eritur an naseat Matrimonia' [concerning the 
Earl of Westmorland's marriage to his late wife's sister] (London, 1562). ${ }^{71}$ It was excoriating. So much so that a Cholmley family history recalled that:

There was a great feud between Sir Richard Chomley and his brother-in-law the Earl of Westmorland, who had married successively two of Richard's sisters, the retainers of the gentleman never met, whether in London streets, or elsewhere, but a fight took place. Their brawls were however attended with less danger to life and less bloodshed than they would have been in succeeding times - for the men fought with buckler and short swords, and it was counted unmannerly to make a thrust. ${ }^{72}$

By 1563, Lady Margaret's life had become an open book. She was the subject of an ecclesiastical commission; her sex life was part of a new lewd print culture; and she was threatened by rumour and condemned by intrigue. But she was not shunned at court. The Nevilles were for one thing too powerful and besides her medical skill was still much in demand. There might have been accusations of poison in the air but most could see that she was someone to consult when in dire medical need. Her reputation for visiting landed families grew for she was valued as a healer and therefore despite intrigues a discrete person to trust. And it is worth remembering that her private medical visits made her a keeper of secrets. These help early modern historians see into the corners of court life where elite women congregated.

For women like Lady Margaret practicing physic was a compelling and dangerous humanist endeavour in the Tudor world. Despite her evident skills, it was easy to be accused of 'darker arts'. Lady Margaret might save a life in the birthing or sick room, but she could just as easily be party to an unexplained death. It was necessary to be circumspect because the line between life and death was fragile. As a healer she was skilled in medical etiquette but also sensible to bring a witness with her to the sickroom. This seems to explain why Lady Margaret's book-collecting activities were monitored from time-to-time by the church courts. One case accused her of 'sometimes despatching another girl, so avoiding any taints for the Lady and hiding her meaning from her family'. ${ }^{73}$ Another witness claimed that she owned 
'profane books'. At one bitter hearing, after she had been called to a woman too late to save either her or the dead infant, she was mocked for her friendships with 'witches and healers'. These were life-threatening accusations that she seems to have withstood by virtue of 'the protection of the Westmorland family', according to the Sarum diocese court scribe.

Lady Margaret is known to have acquired a library of books at Raby that were either destroyed or sold on after the Nevilles fled to Spain following the failure of the Northern Rebellion in 1569. Surviving inventories describe some of her physic books such as $A$ Philosophical discourse of the Body and Soule together with a disposition of them both which was said to contain 'A Hundred Aphorisms conteyning the whole body of Natural Magicke'. ${ }^{74}$ When questioned about her sister's untimely death she quoted a key passage from this text: 'Out of the Apothecaries Shoppe wheare tricks and restoratives are solde men buy the poisons that are the most pestilence'. Lady Margaret liked word play (as many Tudors did) because it disguised uncomfortable truths in a climate of political intrigue at court. One interpretation of her guarded statement is that she took the same view of selfdosing as the medical doggerel of Leonardo da Vinci which opened this chapter. It was a dangerous business to take physic cures prepared by an unskilled, irregular practitioner, or perhaps from the hand of a disappointed husband. When pressed for more details about whether her sister out of desperation to conceive had taken a potion supplied by a medical quack connected to Henry Neville she replied: 'Emptie vessels sound loudest and barren braines are most audacious - A leaking vessel can never fill, nor a person that is ever talking gain knowledge'. It is unclear whether Henry Neville was a dunderhead but he was known as a man of limited intellect at court. Sadly Jane's womb may have been a 'leaking vessel' but this cannot be elaborated since no medical records survive of miscarriages or stillbirths, just that she was barren. Perhaps Jane lacked discretion talking too much about her condition and consulting too many people in her birthing predicament. Other family sources point to Henry, 
as 'ever-talking', loud, not very bright, but basically a moral man, and one with powerful connections at court.

In 1563, after just three short years of marriage, Lady Margaret was widowed. She had no natural Neville children. Curiously the historical record is silent about this outcome perhaps because of the sad circumstances surrounding her sister's death. Given Henry's past sexual history, there is nothing to suggest that his third marriage was not consummated. Nonetheless it may have been more of a marriage of convenience for the sake of his four children, especially as it was sororate, and for appearances sake he always had the option of taking a mistress. The Nevilles were nonetheless very fond of Lady Margaret. As the dowager she withdrew to Lamesleydale, where she lived at Ravensworth Castle. She was now just thirty years old and a good catch in the marriage stakes. There seems though to have been no sense of urgency on her part to remarry. After all, as dowager she had the protection of the first rank of Nobility by marriage with the Nevilles, and their cousins the Arundels, Cliffords and De Vere families. Lady Margaret however between 1563 and her untimely death in 1570 , was to experience the quick erosion of her protection and security. And again this may also have been connected to her physic skills.

Since the accession of Elizabeth I to the throne in 1558, the Northern landed families had been unhappy about her legitimate claims to the throne of England. Memories were long and Lord Henry Neville, a devout Catholic, was a keen enemy of Anne Boleyn's bastard child. He had, after all, witnessed first-hand in 1536 the final scenes of her mother's downfall. The Catholic North now rallied to a new cry, to get rid of Elizabeth I. These political stirrings would culminate in 1569 in the Great Rising in the North led by the Neville family. ${ }^{75}$ Lady Margaret's stepson, Charles, sixth earl of Northumberland, would be roundly defeated, flee to France and thence to Spain as an exile. All the Neville property would be confiscated and redistributed to the Mildmays and Vanes who changed their name to Fane, 
eventually becoming the earls of Westmorland by the seventeenth century. Though complex, this context, proved very serious for Lady Margaret. In character, she was a forthright and passionate woman. She spoke her mind, though tempered by discretion. Soon after her widowhood in 1563, she began to lose support because as the Nevilles weakened their political might in rumbles of rebellion, she too lost ground at court. Increasingly she appears in church court records but now charged with misdemeanours mainly related to her book learning and art of physic. She sent for instance an almanac and some herbal remedies to Oxford University but they evidently took exception to her healing gift and knowledge:

We of Oxford, the Chancellor and his Vice, can with the doctors and masters, all to a man assembled, inform, [you]... But after a grave and maturer debate we moved hereunto by Reason of State, Care at length and agree one and all t'would be better to take it [her almanac] and seem thus to thank you by letter.

This done for we hope you, are herewith content since further than this, nothing by us is Meant.

Our minds we speak plain, without flattering, Preamble, Not skilled, like our sister of Cambridge to dissemble.

We scorn to profess, the least loyal affection to One who against our will, gives us protection we neither wish we nor Pray for, Prince's at Home, Having sent all our Prayers and wishes to Rome, assure yourself therefore We shall find we ever shall hate you, be so ever so kind in token therefore,

Our names we conceal you these Presents, under our Seal. ${ }^{76}$

There are multiple ways to read this letter and so it remains a mystery why the dons of Oxford were so offended by Lady Margaret's gift of an almanac. There is a suggestion in some family papers that Oxford dons were divided over who should refuse to offer their allegiance to Elizabeth I (despite appearances to the contrary). It is noteworthy that Lady Margaret was a widow from a leading Roman Catholic family. The fact that some dons thought fit to remind her that they prayed to Rome, seems to suggest that she was not a practicing Catholic, may in fact have had Protestant tendencies, or she mixed her Catholicism with a form of natural magic that they disliked. Whatever the reason, she inspired strong 
feelings and was increasingly being rebuffed in the public sphere. This may explain why she retreated from court for a time. Regrettably, she then disappears from view by 1569 . A single entry in the burial register of St. Dunstans-in-the-West Church on Fleet Street contains parish records which state that she died at Candlemas in $1570 .{ }^{77}$ The healer was unable in some way to heal herself. By then, the Westmorlands had fled England. The Pope had excommunicated Elizabeth I and conspiracy was in the air. Many men and women would recede into the shadows of court life, retiring to the country until the political carnival had gone full circle again.

\section{Conclusion}

Throughout Henry VIII's reign the survival of noble bloodlines was a medical game of chance and yet vital for the regeneration of Tudor court life. Ambitious families had to overcome daily mishap from disease and misfortune in birthing rites. The evidence in this chapter suggests that the welfare and well-being of the body politic was expressed in family heraldry written into commonplace books with medical doggerel. Thus Henry Peacham in the Complete Gentleman (1622) recalled that at the Henrician Court:

heraldry presents mysterious, quasi-magical correspondences with the planets, nature, times, seasons, and the virtues, so that a character may be read off from a coat of arms. $^{78}$

Others claimed that Tudor heraldry was "the most refined part of Natural Philosophy", having 'close affinities with Neo-Platonism and Hermeticism which together found expression in the court masques and spectacles' commanded by Henry VIII. ${ }^{79}$ At those performances there was a subtle but nonetheless popular understanding that 'vile blood' must not corrupt the body politic of the court. This was one reason why Henry VIII's Commission on Heraldry in 1530 stated that there would be: 
tests of gentility, underwritten by the state, which the heralds were to enforce. Those of "vile blood" (that is, of unfree descent) together with rebels and heretics were excluded. As far as the laity was concerned, the test was to be "service done to us or to another", which had resulted in "possessions and riches able to maintain the same". In the case of the clergy, arms were to be given to those advanced "by grace, virtue or cunning to rooms and degrees of honour and worship". Bishoprics, abbacies, deaneries and priories seem to have been the preferment's meant. ${ }^{80}$

Enforcing this however was no easy matter because large noble households were selfgoverning when not at court. This was why Henry encouraged so many families to be physically present in such large retinues in London. It also explains his strong support for the visitations of heralds around the country or on his summer progress. In more traditional communities, notably amongst the Northern families, there was resentment that royal authority could contravene local customs. In 1533, William Fellows, for instance, noted that visiting gentry acting as heralds encountered what he called: 'downright hostility. Several were not at home; others refused to have any note taken of their arms and pedigrees... in Lancashire local people believed strongly that gentility was a matter of traditional standing and local opinion, which needed no prying inquiry on the part of a king's herald. ${ }^{81}$ It would be a mistake however to conclude that heralds suffered a concerted backlash in the provinces. In many respects heraldry was more highly prized because of royal interference. Larger noble households maintained long-held family customs of belonging and birthright. They disliked the state enquiring into their elevated status. But once raised or reaffirmed by a grant of arms they stubbornly held onto their privileged position. Henry was thus assured of their loyalty because degree and rank gave him the means to divide and rule. He consequently raised much-needed revenue from families anxious to renew their official claims to noble standing at the Royal College of Arms after the Commission on Heraldry of 1533. Against this backdrop, the gossips of the birthing room pronounced the physical resurgence of noble bloodlines and the regeneration of the body politic in its actual medical performance at court. 
Lady Margaret Cholmley's blood ties by birth and marriage, reiterate that women played key roles in the medical life of the court, at its centre and margins. She travelled between large families to assist at their birthing rites, arguably one of the most important aspects of the functioning interior of the Tudor world. Birthing and physic underpinned primogeniture inheritance. Walking with the Cholmley clan and Lady Margaret through the archives is therefore enlightening from a medical standpoint. The fall of the Westmorland clan explains why women who were healers have been historically neglected. Lady Margaret was someone who made a contribution in ways that deserve a more considered historical appreciation of her gender. Her betrothal was not out of the ordinary, but a sororate marriage was contrary to the church's teachings. Her contacts with Oxford University are shrouded in mystery but one thing is certain she stirred up strong feelings, even hatred. Lady Margaret stood in the shadows for reasons of expediency but not because she was bashful. Her footfall in history is there - bread giver, healer, friend, compassionate, learned, shrewd, kindly, attending, feeding and nourishing her kin.

In many respects Lady Margaret reflected the broader changes that were happening in wider Tudor society after the dissolution of the monasteries. Contemporary standards of physic would take new scholarly directions. Physical knowledge of the body slowly divorced from church doctrine. Medical education embraced an anatomical book culture published in the vernacular. In an era of death, death and disease, it was the art and skill of the healer, the performance of better physic that gained popularity. We end this chapter therefore by coming full circle in the writings of Andrew Boorde who wrote a famous Dyetary of Health published in 1542. He advised that good regime was a household duty performed daily in Tudor England:

A good coke is half a physicyon. The chief physic does come from the kitchen wherefore the physicyon and the coke for sycke men must consult together ... Myrth 
is one of the chiefest thynges in Physicke ... There is no man or woman the which hath any to them selfe than can be a better physicyon for their owne safeguard than their own selfe can be, to consider what thing the which doth them good. And refrain from such things that doth hurte or harme. And let every man beware of care, sorrowe, thought, pencyfulness, and of inward anger. Beware of surrfettes, and use not to muche veneryouse actes. Breake not the usual custom of sleep in the night. A mery heart and minde, the which is in rest and quyetness, without adversyte and to mouche workdly business causes a man ... care and sorrowe, bringing in old age and death. ${ }^{82}$

This medical regime (like that of Leonardo da Vinci which opened this chapter) was neglected by King Henry VIII until ill-health forced him to pay more attention to its advice. He did patronise a male-medical fraternity of regular physic (physicians, barber-surgeons and apothecaries). The language of patriarchy thus dominated the body of the Henrician court. Yet physic was being administered by a complex array of new medical actors, irregulars, and many were female. In 1542, Andrew Boorde advised such women 'to nurse the sicke man' but to 'have few words or none' except the 'Testament' [Bible] if the person is very ill. ${ }^{83}$ The fact that he addressed the female healer unambiguously reiterates their physical presence, medical skills, and spiritual duties, at the heart of the crowded Henrician court. In that world, Lady Margaret's skill served changing cultures of the body. She personifies the medical proficiency acquired by many elite women bequeathed in marriage to elderly husbands, exemplified by Queen Katherine Parr the nursemaid of a dying King Henry VIII in 1547.

(C2011, Dr. Elizabeth T Hurren, Reader in the History of Medicine, Oxford Brookes University: ehurren@brookes.ac.uk (9, 500 words - 12, 000 with endnotes)

\footnotetext{
${ }^{1}$ C. Nicholls, Leonardo da Vinci: The Flights of the Mind (London and New York, 2005: Penguin Books), pp. 486-93.

${ }^{2}$ Ibid., p. 477-8.
} 


\footnotetext{
${ }^{3}$ Seen in the famous Hans Holbein painting in which 'King Henry VIII gives a new charter to The Company of Barber Surgeons in 1540' - for context on this and the large physic garden that the monarch patronised, see, the website of the Worshipful Company of Barber Surgeons today at www.barberscompany.org/hall.html.
}
${ }^{4}$ See, Rawdon Brown and Allen B. Hinds (eds) Calendar of State Papers and Manuscripts, Relating to English Affairs, Existing in the Archives and Collections of Venice and other Libraries of Northern Italy, 38 Volumes, (London, 1854-1947: Longman and Co), hereafter, CSPVen, Volume I, 176.

\begin{abstract}
${ }^{5}$ See, Allen B Hinds (ed) Calendar of State Papers and Manuscripts, Existing in the Archives and Collections of Milan, (London, 1912: HM Stationary Office) and cited in, for instance, Carolly Erickson, Great Harry: The
\end{abstract} Extravagant Life of Henry VIII, (London and New York, 2004: Simon and Schuster), p. 91.
${ }^{6}$ Erickson, Great Harry, pp. 90-1. This account still provides one the best summarises of Henry's physical condition and medical profile; the latter has tended to be understudied, see also, chapter 44, pp. 359-67.

${ }^{7}$ Ibid., pp. 362-3.

\author{
${ }^{8}$ The National Archives, Calendar of State Papers, Part I, State Papers Domestic, 1509-93, SP 1/35 f.149. \\ 1526.
}
${ }^{9}$ Note: the second suit of armour in 1536 was made just before his last jousting accident; and by 1541 the Royal armourer wrote that he was 'very stout', see, J. F. D. Shrewsbury, 'Henry VIII, a Medial Study', Journal of the History of Medicine and Allied Science, ,Volume VII (Spring, 1952), pp. 141-185, quote at p. 176.

${ }^{10}$ See, J. S. Brewer, R. H. Brodie and James Gardiner (eds), Letters and Papers, Foreign and Domestic of the Reign of Henry VIII, 21 volumes (London, 1862-1910: Her Majesty's Stationary Office), L.P., Volume XII: ii, 394 for his apothecaries and their cures in 1546-7; Blaxland Stubbs, 'Royal Recipes for Plasters, Ointments and Other Medications', The Chemist and Druggist, CXIV, Special Medical Issue, (June, 1931), pp. 792-4, also gives one of the few detailed accounts of the Royal apothecary's work for Henry's constipation and ulcers.

${ }^{11}$ A viewpoint established by Henry's first Royal biographer, Edward, Lord Herbert of Cherbury, The life and raigne of King Henry the eighth (London, 1649), subsequently developed in Charles Oman, 'The Personality of Henry VIII', Quarterly Review, CCLXIX, (July 1937), pp. 88-104, and recently expanded upon in David Starkey, Henry: Virtuous Prince, (New York and London, 2009: Harper Perennial). 
${ }^{12}$ See context, in, Peregrine Horden and Richard Smith, The Locus of Care: Families, Communities, Institutions and the Provision of Welfare since Antiquity (London, 1997: Routledge Studies in the Social History of Medicine series).

${ }^{13}$ Refer, Francis Romeril Madison, Margaret Pelling, Charles Webster, Linacre Studies: Essays on the Life and Work of Thomas Linacre, 1460-1524, (Oxford, 1977: Oxford University Press); Margaret Pelling, The Common Lot: Sickness, Medical Occupations and Urban Poor in Early Modern England, (London, 1988: Longman); Margaret Pelling, Medical Conflicts in Early Modern London: Patronage, Physicians and Irregular Practitioners, 1550-1640, (Oxford, 2003: Oxford University Press Studies in Social History Series); Margaret Pelling and Scott Mandelbrote, The Practice of Reform in Health. Medicine and Science, 1500-2000, (London, 2005: Ashgate).

${ }^{14}$ For an important overview, see, David Cressy, Birth, Marriage and Death: Ritual, Religion and the Life Cycle in Tudor and Stuart England, (Oxford, 1997: Oxford University Press)

${ }^{15}$ Thomas Woodcock and John Martin Robinson, The Oxford Guide to of Heraldry, (Oxford, 1990: Oxford University Press); W. H. St. John Hope and Antony R. Wagner, A Grammar of English Heraldry, (Cambridge, 2011 edition: Cambridge University Press)

${ }^{16}$ See, for example, J. P. D. Cooper, Propaganda and the Tudor State: Political Culture in the West Country, (Oxford, 2003: Clarendon Press)

${ }^{17}$ See, notably, on the Norfolk Nobility, Jessie Childs, Henry VIII's Last Victim: The Life and Times of Henry Howard Earl of Surrey (London, 2008: Vintage Press).

${ }^{18}$ The most comprehensive account of its workings is still found in, G. D. Squibb, The High Court of Chivalry: A Study in the Civil Law of England (Oxford, first published 1959, reissued 1997: Clarendon Press).

${ }^{19}$ David Starkey, Six Wives: The Queens of Henry VIII, (London, 2004: Vintage), pp. 106-7 describes in detail the close relationship between Mountjoy, scholar and mentor to Henry (thirteen years younger).

${ }^{20}$ The Royal College of Arms, MS Vincent Collection, folio 403, Lord Mountjoy family doggerel. 
${ }^{21}$ There is a large historiography on the early Reformation in Tudor England. For an important overview, see, Eamon Duffy, The Stripping of the Altars: Traditional Religion in England, 1400-1580, (Yale, New Haven, 2005: Yale University Press).

${ }^{22}$ See, for example, Christopher Haigh, English Reformations: Religion, Politics and Society under the Tudors, (Oxford, 1993: Clarendon Press).

${ }^{23}$ All quotations are taken from the King James Version of the Bible, $1{ }^{\text {st }}$ Corinthians, Chapter 12 even though Henry would have read the Vulgate in Greek or Latin Scripture.

${ }^{24}$ For recent scholarship on the history of Natural Fools, see, Suzannah Lipscomb, 'All the King's Fools', History Today, volume 61 (2011) issue 8, and 'All the King's Fools', a public engagement project and theatre production at Hampton Court Palace in partnership with Foolscap and the Misfits Theatre Company (October 2011) sponsored by the Wellcome Trust with Suzannah Lipscomb, Thomas Betteridge and Elizabeth Hurren (historical consultants), Oxford Brookes University.

${ }^{25}$ For context, see, Carole Rawcliffe, Medicine and Society in Later Medieval England (London, 1995: Sutton Publishing Ltd); Mary Lindemann, Medicine and Society in Early Modern Europe: New Approaches to European History, (Cambridge, 1999: Cambridge University Press); Andrew Wear, Knowledge and Practice in English Medicine, 1550-1680, (Cambridge, 2000: Cambridge University Press)

${ }^{26}$ Sir Hugh Chomley, Some Passages from a History of the Cholmley Family, (York and London, 1652), p. 16.

${ }^{27}$ On the practice of astrology and medicine, see, notably, Gerhild Scholz Williams and Charles, D. Gunnoe, Paracelsian Moments: Science, Medicine and Astronomy in Early Modern Europe: Sixteenth Century Essays and Studies, (Turman, USA, 2003: Truman State University Press).

${ }^{28}$ Links between heraldry, astrology, and medicine have been understudied during Henry's reign. For a recent appraisal of popular trends during the later Tudors, see, Lauren Kassell, Medicine and Magic in Elizabethan London: Simon Forman, Astrologer, Alchemist and Physician, (Oxford, 2007 edition: Oxford University Press) and Louise Hill Curth, English Almanacs, Astrology and Popular Medicine, 1550-1700, (Manchester, 2007: Manchester University Press).

${ }^{29}$ Erickson, Great Harry, p. 22, outlines his childhood profile. 
${ }^{30}$ See, notably, Peregrine Horden, Music as Medicine: The History of Music Therapy since Antiquity (London, 2001: Ashgate)

${ }^{31}$ See, for example, contemporary thinking in, Andrew Rawdon, A Compendyous Regyment or a Dyetary of Helth in F. J. Furnivall (ed), Early English Text Society, Extra Series, $X$ (London, 1870: Trübner).

${ }^{32}$ A useful summary can still be found in, John Stevens (ed) Music at the Court of Henry VIII: Musica Britannica, Volume XVIII, (London, 1962: Stainer and Bell)

${ }^{33}$ On her life story, see, Michael K. Jones and Malcolm K Underwood, The King's Mother: Lady Margaret Beaufort, Countess of Richmond, (Cambridge, 1993: Cambridge University Press)

${ }^{34}$ For Tudor birthing, refer, Boyd. M. Berry, 'The First English Paediatricians', Journal of the History of Ideas, XXXV, 4, (October-December 1974), pp. 561-77.

${ }^{35}$ The reliability of Tudor diplomatic exchanges has been questioned by early modern historians. General trends and common observations are therefore referred to in this chapter for reasons of accuracy.

${ }^{36}$ Refer, Hector MacLennan, 'A Gynaecologist Looks at the Tudors', Medical History, XI, 1 (January, 1967), pp. 66-74; There has recently been an attempt by an anthropologist and bio-archaeologist to rethink the medical problems of Henry VIII and his wives from a genetic standpoint, see, Catrina Banks Whitley and Kyra Kramer, 'A New Explanation for the Reproductive Woes and Midlife Decline of Henry VIII', Historical Journal, 53 (2010), issue 4, pp.827-848.

${ }^{37}$ Family history reconstructed from record linkage work on Sir Hugh Chomeley, Some Passages from a History of the Cholmley Family, (York and London, 1652), pp. 1-16; Buxton MS, Family Papers, Cambridge University Library Manuscript Department; The Cholmley MS, Family Probate and Wills, Borthwick Institute for Archives, York; Cholmley and Strickland of Whitby MS, Family papers, North Yorkshire County Record Office, Durham.

${ }^{38}$ Ibid, Sir Hugh Cholmely, Some Passages, p. 388

${ }^{39}$ An excellent appraisal of the Tudor peerage and their Noble standing can be found in, G. W Bernard (ed), The Tudor Nobility, (Manchester, 1992: Manchester University Press). 
40 There was also an illegitimate son who lived in Essex and famously founded in 1565 by Royal Charter Sir Roger Cholmley's School at Highgate in London which is still educating children today. The illegitimate Sir Roger did not inherit the Yorkshire landholdings which were entailed to the legitimate line of Sir Richard.

${ }^{41}$ Sir Hugh Cholmley, Some Passages, p.388-9.

${ }^{42}$ Ibid.

${ }^{43}$ They had three girls and two male heirs that survived to adulthood. The heir was Sir Henry Cholmley of Whitby who married Margaret Babthorpe and the spare brother was styled John Cholmley of Yorkshire.

${ }^{44}$ Sir Hugh Cholmley, Some Passages, p. 388-9.

${ }^{45}$ Ibid. all quotations taken from the family history have been verified from record linkage work on family papers, see footnote 36 above.

${ }^{46}$ See David R Parker, The Commonplace Book in Tudor London, (New York and London, 1998: University Press of America).

${ }^{47}$ See, notably, Mary Hazard, The Elizabethan's Silent Language (New York, 2000: Nebraska Press)

${ }^{48}$ Richard Verstegan cited in, Hazard, Elizabethan's Silent Language, p.129

${ }^{49}$ Ibid. p. 129

${ }^{50}$ This medical mentality is elaborated further in an important collection by essay by, P. Crawford, Blood, Bodies and Families in Early Modern England, (London and New York, 2004: Longman Books).

${ }^{51}$ There are a lot of references to this Constable family line in, for instance, J. S. Brewer (ed), Letters and Papers, Foreign and Domestic, Henry VIII, Volume 1, 1509-1514, Pardon Roll, Part 3, (London, 1920) pp. 234-256 and online at http://www.british-history.ac.uk/report.aspx?compid=102634.

${ }^{52}$ An historical trend exemplified in recent literary studies on this topic, see, for example, T. Betteridge and Anna Riehl, Tudor Court Life (Sussquehanna, USA, 2010: Sussquehanna Press); for change over time, see also, David Loades, Intrigue and Treason: The Tudor Court, 1547-1558 (London and New York, 2004: Longman). 
${ }^{53}$ Barbara J. Harris, English Aristocratic Women, 1450-1550: Marriage and Family, Property and Careers, (Oxford, 2002: Oxford University Press).

${ }^{54}$ This historical approach using new archive work on the Cholmley females builds on recent gender studies by exploring the pragmatic ways in which women navigated and expressed their identity together in the private and public spheres in Tudor times, refer, Ulricke Tancke, Bethinke Thyself in Early Modern England: Writing Women's Identities, (Amsterdam, 2010: Rodopi),

${ }^{55}$ Charles R. Young, The Making of the Neville Family in England, 1166 -1400 (Woodbridge, Sussex, 1996: Boydell and Brewer Press).

${ }^{56}$ Henry Neville (1525-1564) $5^{\text {th }}$ Earl of Westmorland, succeeded to his family title in 1550 . He was a Privy Councillor and Ambassador to Scotland, and was appointed a Knight of the Garter in 1552. At Edward VI's and Mary's coronation he bore the second sword of state and cap of maintenance. He married three times: Anne 1536; Jane 1550; Margaret 1559 and held the title of Lord Lieutenant of the North.

${ }^{57}$ For further context, refer, Sara Mendleson and Patricia Crawford, Women in Early Modern England, 15501720, (Oxford, 2000: Oxford University Press).

${ }^{58}$ Sir Hugh Cholmley, Some Passages, p. 388-9.

${ }^{59}$ R. Hoyle, The Pilgrimage of Grace and the Politics of the 1530s, (Oxford, 2003: Oxford University Press), recounts the position of the Cholmleys and Neville clans in the North.

${ }^{60}$ This claim was made in family histories and, as we shall see below, was verified in several court cases during her lifetime.

${ }^{61}$ I am grateful to Professors Peregrine Horden and Pauline Croft, and Dr. Caroline Bowden, 'The Health of the Cecils Research project sponsored by the Wellcome Trust, 2003-2007' for permitting me to share their medical findings at an academic symposium held at All Souls College in Oxford, 2008-9.

${ }^{62}$ Many of their books were discovered in various College libraries in Oxford and one key aim of the project has been to document their book collections and medical ephemera. 
${ }^{63}$ Elizabeth Mazzola, Women's Wealth and Women's Writing in Early Modern England: "Little Legacies" and the Materials of Motherhood, (London, 2009: Ashgate), details how Bess of Hardwicks's female line shared a similar form of intellectual, material and, practical household knowledge.

${ }^{64}$ Linda A. Pollock, With Faith and Physic: The Diary of a Tudor Gentlewoman - Lady Grace Mildmay, $1552-$ 1620, (London and New York, 1993: Collins and Brown)

${ }^{65}$ The birthing and healing skills of Lady Margaret are documented in some detail in Wiltshire Record Office, Sarum Diocese Consistory Court Records, Instant Books, D39/1/16 and the corresponding Deposition Books, D1/42/6 and D1/42/7.

${ }^{66}$ Lauren Kassell, 'Secrets Revealed: Alchemical Books in Early-Modern England', History of Science, XLVIII, (March, 2011), pp. 1-27

${ }^{67}$ Recently in the cultural history of the body, these herbal activities have started to be appreciated from a medical standpoint, see, recently, Rebecca Larouche, Medical Authority and Englishwomen's Herbal Texts, 1550-1650, (London, 2009: Ashgate).

${ }^{68}$ See n. 64 above.

${ }^{69}$ For an important book on this aspect of birthing, see, Mary Fissell, Vernacular Bodies: The Politics of Reproduction in Early Modern England (Oxford, 2004: Oxford University Press)

${ }^{70}$ Refer quotation, http://www.arapacana.com/glossary/si_ss.html and for a recent academic appraisal, F. Heritier, Two Sisters and their Mother: The Anthropology of incest (Massachusetts, 2002: MIT Press)

${ }^{71}$ University College London, Manuscript Department, John Hales's 'Comes Westmerlandiae ducit in uxorem sororem uxoris demortuae, Eritur an naseat Matrimonia' [concerning the Earl of Westmorland's marriage to his late wife's sister] (London, 1562). John Hales of Coventry and Kent was known at the Henrician Court as 'ClubFoot Hales because in his younger days he had got that deformity by a wound from his own dagger at the bottom of his foot ... he had a happy memory accompanied by incredible industry, well skilled in Latin, Greek and Hebrew tongues, and at length in the municipal laws and antiquities ... In the reign of Henry VIII he was clerk of the hamper (or hanaper, a profitable office of chancery that sealed deeds, now defunct) for several years and obtained a fair estate in Warwickshire where he wrote The Highway to Nobility and translated Precepts for 
the Preservation of Health', see, John Burke, A genealogical and heraldic history of extinct baronetcies

(London, 1842: Genealogical Publishing Company), p. 222

${ }^{72}$ Sir Hugh Cholmley, Some Passages, p. 390-1.

${ }^{73}$ See n. 64 above.

${ }^{74}$ An inventory of these books was purchased by Sir Christopher Hatton of Holdenby after the Nevilles of Raby fled to Spain, and had all their land, titles and property confiscated in 1569. See, Northamptonshire Record Office, Finch-Hatton Collection, Box 4020, folio 494, 'A Catalogue of Artis Cabalisticae he reconditae Theologiae et Philosophiae Scriptorium Tomus ex Pistorii Bibliothea Basilea unbound, pp. 1-136'.

${ }^{75}$ For context, see, K. J. Kesselring, The Northern Rebellion of 1569: Faith, Politics and Protest in Elizabethan England, (Basingstoke, 2010: Palgrave).

${ }^{76}$ Northamptonshire Record Office, Westmorland Collection, Box 4, Parcel 4, folio 4, 'A letter from the University of Oxford addressed to the Countess of Westmorland'.

${ }^{77}$ Guildhall Library, London, MS 10343, Parish Register of Deaths, St. Dunstan-in-the-West Church, 1570.

${ }^{78}$ Henry Peacham, The Complete Gentleman (London, 1622), p. 408.

${ }^{79}$ James Mervyn, Society, Politics and Culture: Studies in Early Modern Culture (Cambridge, 1986: Cambridge University Press), p 408.

${ }^{80}$ Ibid., p. 336.

${ }^{81}$ Ibid., p. 338.

${ }^{82}$ Andrew Boorde, The First Book of the introduction of Knowledge: A Compendious Regiment or a Dietary of Health, Made in Montpellier, Barnes in the Defense of the Berde (London, 1543), p. 300.

${ }^{83}$ Ibid, p. 301. 